\title{
Serum levels of 25-hydroxy vitamin D in psoriatic patients*
}

\author{
Manuela Ferrasso Zuchi ${ }^{1}$ \\ Anber Ancel Tanaka ${ }^{1}$ \\ Luis Eduardo Agner Machado Martins ${ }^{1}$
}

\author{
Paula de Oliveira Azevedo ${ }^{1}$ \\ Juliano Vilaverde Schmitt ${ }^{2}$
}

DOI: http:/ / dx.doi.org/10.1590/abd1806-4841.20153524

\begin{abstract}
A bstract: Studies have shown a relationship between vitamin D and psoriasis. We compared serum levels of vitamin D of 20 psoriasis patients and 20 controls. The median vitamin D level was $22.80 \pm 4.60 \mathrm{ng} / \mathrm{ml}$; the median in the cases was $23.55 \pm 7.6 \mathrm{ng} / \mathrm{ml}$, and in controls $22.35 \pm 3.10 \mathrm{ng} / \mathrm{ml}(\mathrm{p}=0.73)$. Only 2 cases and 4 controls had sufficient levels of vitamin D, although without statistical significance between the groups ( $p=0.608$ ). Levels were lower in women with psoriasis compared with those in male patients $(20.85 \pm 6.70 \times 25.35 \pm 2.90 \mathrm{ng} / \mathrm{ml}, \mathrm{p}=$ 0.03), a finding that was not observed among controls.
\end{abstract}

Keywords: Psoriasis; Vitamin D; Vitamin D deficiency

Psoriasis is a systemic, inflammatory, chronic autoimmune disease that affects between 1 and $3 \%$ of the global population. ${ }^{1}$ Its pathogenesis is not totally clear, but it is a known fact that there is activation of sectors of innate and adaptive immune response. ${ }^{2,3}$

Vitamina D (25-hydroxyvitamin D) is a hormone whose synthesis is stimulated by cutaneous exposure to ultraviolet $B$ radiation. ${ }^{4}$ It acts on calcium homeostasis, on bone metabolism and has immune regulating functions that have been recently recognized. ${ }^{5}$ Some studies have demonstrated a relationship between vitamin D deficiency and psoriasis. ${ }^{6,7}$

This study compares serum levels of vitamin D of 20 adults with active psoriasis and 20 patients seen at the outpatient dermatology clinic of the Teaching Hospital of the Evangelical College of Curitiba, in Curitiba - PR, between July and September of 2013. Those patients who were using medications that interfere on vitamin D levels, were undergoing photother- apy, had inflammatory or disabsortive bowel disease, liver disease, chronic kidney insufficiency and other autoimmune disorders were excluded.

The analysis of vitamin D serum levels was performed by chemiluminescent immuneassay and values $<20 \mathrm{ng} / \mathrm{ml}$ were considered deficiency, from 20 to $<30 \mathrm{ng} / \mathrm{ml}$ insufficiency and $\geq 30 \mathrm{ng} / \mathrm{ml}$ sufficiency.

Statistical data were evaluated by the following tests: Fisher's Exact, Student's t, Mann-Whitney, Spearman and ANCOVA; the values were considered significant when $\mathrm{P}<0.05$.

The group of cases was composed of 12 women and 8 men, aged between 19 and 76 years (mean age $46.40 \pm 14.90$ years) and median disease duration $42 \pm 108$ months. As to the type of psoriasis, 5/20 had palmoplantar psoriasis and $15 / 20$ psoriasis vulgaris with median PASI (Psoriasis A rea and Severity Index) $2.4 \pm 3.6$ and a DLQI (D ermatology Life Quality Index) of $4.5 \pm 6.0$.

Received on 10.03.2014

Approved by the Advisory Board and accepted for publication on 26.05.2014

Study carried out at the Dermatology Service of the Teaching Hospital of the Evangelical College of Curitiba (HUEC-FEPAR) - Curitiba (PR), Brazil.

Financial Support: None.

Conflict of Interest: None.

Faculdade Evangélica do Paraná (FEPAR) - Curitiba (PR), Brazil.

Universidade Estadual Paulista "Júlio de Mesquita Filho" (UNESP) - Botucatu (SP), Brazil.

C2015 by Anais Brasileiros de Dermatologia 
The control group was composed of 20 patients (14 women and 6 men), aged between 19 and 84 years (mean $47.80 \pm 18.86$ years).

Table 1 shows demographic data and serum levels of 25-hydroxyvitamin D in the patients. Distributions by gender, age and phototype were not significantly different. Only 2 cases and 4 controls presented sufficient levels of vitamin D. Including all of the participants in the study, the median vitamin D level was $22.80 \pm 4.60$ and it was lower in those that were exposed to sunlight for less than 30 minutes per day $(P=0.04)$.

We did not find significant differences in vitamin D levels between patients with psoriasis and controls $(P=0.735)$. Wilson et al carried out a study using the National Health and Nutrition Examination Survey (NHANES) information base and found, in a group of 5841 individuals, 148 patients with psoriasis that were compared to the 5693 individuals without the disease. The investigators did not report differences in serum levels or deficiency of vitamin D between the patients with and without psoriasis, with prevalence of deficiency in $33 \%$ and $34.9 \%$ of the participants with and without the disease, respectively. ${ }^{8}$

Orgaz-Molina et al, however, observed lower serum levels of vitamin $\mathrm{D}$ in patients with psoriasis when compared with controls; $25.6 \%$ of the individuals with psoriasis and $93 \%$ dos controls presented deficiency of this hormone. ${ }^{7}$ In the study by Gisondi et al, the participants with psoriasis presented a risk 2.5 times greater of having 25-hydroxyvitamin D deficiency than those without the disease. ${ }^{9}$ Ricceri et al found a prevalence of $68 \%$ of vitamin D deficiency and $97 \%$ of insufficiency in the patients with psoriasis studied, while the percentages found in the control group were $10 \%$ of deficiency and approximately $53 \%$ of insufficiency of this hormone. ${ }^{10}$

TABLE 1: Comparison of variables studied between the psoriasis group and the control group

\begin{tabular}{|c|c|c|c|c|c|}
\hline \multicolumn{2}{|c|}{ Variable } & \multirow{2}{*}{$\begin{array}{l}\text { Psoriasis } \\
(\mathbf{n}=\mathbf{2 0})\end{array}$} & \multirow{2}{*}{$\begin{array}{l}\text { Controls } \\
(n=20)\end{array}$} & \multirow{2}{*}{$\begin{array}{l}\text { Odds ratio } \\
\text { Reference }\end{array}$} & \multirow{2}{*}{$\begin{array}{l}\mathbf{p} \\
-\end{array}$} \\
\hline $\operatorname{Sex}^{1}$ & Females & & & & \\
\hline & Males & 8 & 6 & $1.56(0.42$ to 5.76$)$ & $0.531^{2}$ \\
\hline Current age $^{3}$ & & $46.40 \pm 14.90$ & $47.80 \pm 18, .6$ & - & $0.860^{4}$ \\
\hline \multirow[t]{3}{*}{ Phototype $^{1}$} & $1-2$ & 10 & 11 & Reference & - \\
\hline & 3 & 4 & 5 & $0.88(0.18$ to 4.23$)$ & $0.999^{2}$ \\
\hline & $4-5$ & 6 & 4 & $1.65(0.36$ to 7,60$)$ & $0.704^{2}$ \\
\hline \multicolumn{2}{|c|}{ Daily direct sun exposure (min. $)^{5}$} & $25.0 \pm 10.0$ & $35.0 \pm 100.0$ & - & $0.156^{6}$ \\
\hline \multicolumn{2}{|c|}{ 25-Hydroxyvitamin $\mathrm{D}^{5}$} & $23.55 \pm 7.60$ & $22.35 \pm 3.10$ & - & $0.735^{6}$ \\
\hline \multicolumn{2}{|c|}{ Deficiency $\mathrm{VD}^{1,7}$} & 5 & 4 & Reference & - \\
\hline \multicolumn{2}{|c|}{ Insufficiency VD ${ }^{1,7}$} & 13 & 12 & $0.87(0.19$ to 4.01$)$ & $0.999^{2}$ \\
\hline \multicolumn{2}{|c|}{ Sufficiency VD $\mathrm{VD}^{1,7}$} & 2 & 4 & 0.40 (0.05 to 3.42$)$ & $0.608^{2}$ \\
\hline
\end{tabular}

1. Represented by absolute numbers. 2. Fisher's Exact test. 3. Means and standard deviations. 4. Unpaired Student's t-test. 5. Medians and interquartile deviation. 6. Nonparametric Mann-Whitney test. 7. VD: Vitamin D; Strata defined according to reference values of the laboratory performing serum dosage of 25-hydroxyvitamin D: deficiency ( $<20 \mathrm{ng} / \mathrm{ml})$, insufficiency $(>=20$ and $<30 \mathrm{ng} / \mathrm{ml})$ and sufficiency $(>=30 \mathrm{ng} / \mathrm{ml})$.

TABLE 2: Comparison of men and women with psoriasis

\begin{tabular}{|c|c|c|c|c|c|}
\hline \multicolumn{2}{|l|}{ Variable } & $\begin{array}{l}\text { Female } \\
(n=12)\end{array}$ & $\begin{array}{l}\text { Male } \\
(n=8)\end{array}$ & Odds ratio & $\mathrm{p}$ \\
\hline \multicolumn{2}{|l|}{ Current age $^{1}$} & $43.50 \pm 14.00$ & $50.50 \pm 31.00$ & - & $0.537^{2}$ \\
\hline \multirow[t]{2}{*}{ Phototype $^{3}$} & $1-2$ & 6 & 4 & Reference & - \\
\hline & $3-5$ & 6 & 4 & $1.00(0.17$ to 5.98$)$ & 0.9994 \\
\hline \multicolumn{2}{|c|}{ Age of psoriasis onset (years) ${ }^{1}$} & $38.58 \pm 12.41$ & $33.38 \pm 27.12$ & - & 0.5892 \\
\hline \multicolumn{2}{|c|}{ PASI $^{5,6}$} & $1.70 \pm 3.40$ & $3.20 \pm 5.70$ & - & 0.2177 \\
\hline \multicolumn{2}{|c|}{ DLQI $^{5,8}$} & $2.50 \pm 3.00$ & $7.50 \pm 5.00$ & - & 0.1147 \\
\hline \multicolumn{2}{|c|}{ Daily direct sun exposure (min. $)^{5}$} & $20.0 \pm 10.0$ & $45.0 \pm 40.0$ & - & 0.0497 \\
\hline \multicolumn{2}{|c|}{ 25-Hydroxyvitamin $\mathrm{D}^{5}$} & $20.85 \pm 6.70$ & $25.35 \pm 2.90$ & - & 0.0317 \\
\hline
\end{tabular}

1. Means and standard deviations. 2. Unpaired Student's t-test. 3. Represented by absolute numbers. 4. Fisher's Exact test. 5. Medians and interquartile deviation. 6. “Psoriasis Area Severity Index”. 7. Nonparametric Mann-Whitney test. 8. “Dermatology Life Quality Index”. 
Our study also found association between serum levels of vitamin D and gender. Vitamin D levels were lower in women with psoriasis in comparison with men $(P=0.03)$, a fact not observed among controls $(P=0.62)$. The median daily sun exposure time was also shorter in women with psoriasis compared with men with psoriasis $(P=0.049)$, which also did not occur with controls $(P=0.99)$. This association may be due to the relatively small number of cases or some uncontroled variable, like wearing cosmetics with sunscreen effect, more common among women. ${ }^{7}$ In spite of this, the covariance analysis of the group of psoriasis patients, controled by daily sun exposure levels, showed that the female gender was associated with lower levels of vitamin D independently from time of sun exposure $(P=0.01)$. Table 2 illustrates the characteristics of patients with psoriasis according to gender. The studies conducted by Orgaz-Molina et al and Ricceri et al, which also evaluated these variables, did not find significant differences between vitamin D levels and gender. ${ }^{7,10}$

Vitamin D insufficiency was very frequent in this population, although no significant differences were found in vitamin $D$ serum levels between patients with psoriasis and other dermatology patients.

\section{REFEREN CE}

1. Raychaudhuri SP, Farber EM. The prevalence of psoriasis in the world. J Eur Acad Dermatol Venereol. 2001;15:16-7.

2. Arruda LHF, Campbell GAM, Takahashi MDF. Psoriasis. An Bras Dermatol. 2001;76:141-67.

3. Paula A, Sanchez G. Immunopathogenesis of psoriasis. An Bras Dermatol. 2010;85:747-9.

4. Maia M, Maeda SS, Marçon C. Correlation between photoprotection and 25 hydroxyvitamin D and parathyroid hormone levels. An Bras Dermatol. 2007;82:233-7.

5. Marques CDL, Dantas AT, Fragoso TS, Duarte ALBP. The importance of vitamin D levels in autoimmune diseases. Rev Bras Reum. 2010;50:73-80.

6. Szodoray P, Nakken B, Gaal J, Jonsson R, Szegedi A, Zold E, et al. The complex role of vitamin D in autoimmune diseases. Scand J Immunol. 2008;68:261-9.

7. Orgaz-Molina J, Buendía-Eisman A, Arrabal-Polo MA, Ruiz JC, Arias-Santiago S. Deficiency of serum concentration of 25-hydroxyvitamin D in psoriatic patients: a case-control study. J J Am Acad Dermatol. 2012;67:931-8.

8. Wilson PB. Serum 25-hydroxyvitamin D status in individuals with psoriasis in the general population. Endocrine. 2013;44:537-9.

9. Gisondi P, Rossini M, Di Cesare A, Idolazzi L, Farina S, Beltrami G, et al. Vitamin D status in patients with chronic plaque psoriasis. Br J Dermatol. 2012;166:505-10.

10. Ricceri F, Pescitelli L, Tripo L, Prignano F. Deficiency of serum concentration of 25-hydroxyvitamin $D$ correlates with severity of disease in chronic plaque psoriasis. J Am Acad Dermatol. 2013;68:511-2.

\author{
M AILING ADDRESS: \\ $M$ anuela Ferrasso Z uchi \\ Carlos de Carvalho, 1652 - Batel \\ 80730-200 - Curitiba - PR \\ Brazil \\ E-mail: manuzuchi@hotmail.com
}

How to cite this article: Zuchi MF, Azevedo PO, Tanaka AA, Schmitt JV, Martins LEAM. Serum levels of 25-hydroxy vitamin d in psoriatic patients. An Bras Dermatol. 2015; 90(3):430-2. 